\title{
Frontiers in Zoology
}

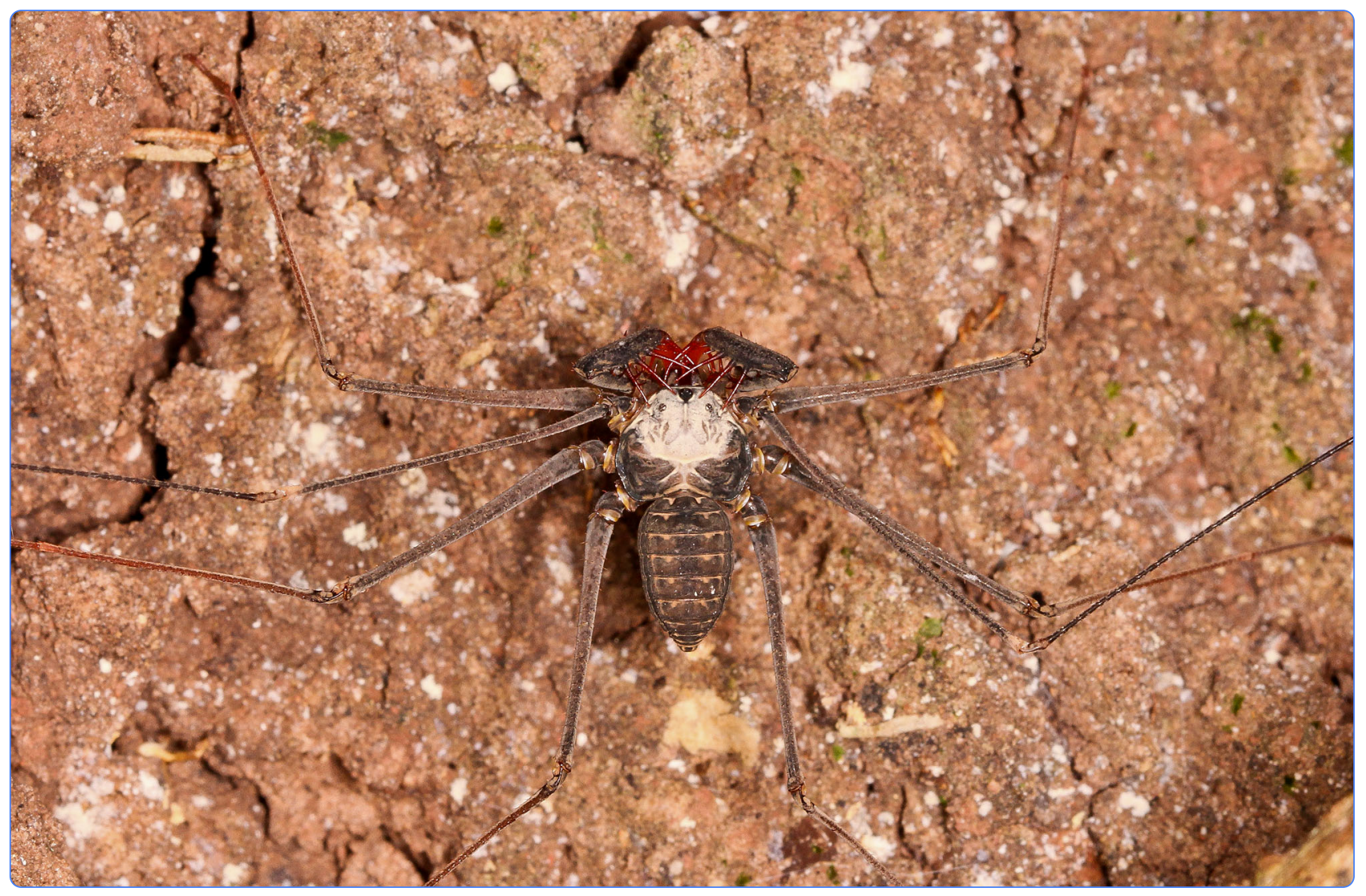

\section{Also looking like Limulus? - retinula axons and visual neuropils of Amblypygi (whip spiders)}

Lehmann and Melzer 


\title{
Also looking like Limulus? - retinula axons and visual neuropils of Amblypygi (whip spiders)
}

Tobias Lehmann ${ }^{1,2^{*}}$ (D) and Roland R. Melzer ${ }^{1,2,3}$

\begin{abstract}
Background: Only a few studies have examined the visual systems of Amblypygi (whip spiders) until now. To get new insights suitable for phylogenetic analysis we studied the axonal trajectories and neuropil architecture of the visual systems of several whip spider species (Heterophrynus elaphus, Damon medius, Phrynus pseudoparvulus, and P. marginemaculatus) with different neuroanatomical techniques. The R-cell axon terminals were identified with Cobalt fills. To describe the morphology of the visual neuropils and of the protocerebrum generally we used Wigglesworth stains and $\mu \mathrm{CT}$.

Results: The visual system of whip spiders comprises one pair of median and three pairs of lateral eyes. The R-cells of both eye types terminate each in a first and a second visual neuropil. Furthermore, a few R-cell fibres from the median eyes leave the second median eye visual neuropil and terminate in the second lateral eye neuropil. This means R-cell terminals from the lateral eyes and the median eyes overlap. Additionally, the arcuate body and the mushroom bodies are described.
\end{abstract}

Conclusions: A detailed comparison of our findings with previously studied chelicerate visual systems (i.e., Xiphosura, Scorpiones, Pseudoscorpiones, Opiliones, and Araneae) seem to support the idea of close evolutionary relationships between Xiphosura, Scorpiones, and Amblypygi.

Keywords: Chelicerata, Arachnida, Visual system, Central projections, Phylogeny

\section{Background}

The around 190 species of the arachnid order of Amblypygi (whip spiders or tailless whip scorpions) inhabit subtropical or tropical regions worldwide [1]. Most species occur in rain forests, only a few in savannahs or deserts, and all species are nocturnal predators. They can be found in leaf litter, underneath bark or stones, or in caves [2]. Fossil whip spiders are rare; the oldest specimens are known from the Late Carboniferous (ca. $310 \mathrm{Ma}$ ) [3, 4].

Their main sense organs are the antenniform legs (first pair of legs) and in particular their distal tarsi. These legs are no longer used for walking but are modified extremities carrying various sensilla (contact chemoreceptors,

\footnotetext{
* Correspondence: lehmann@snsb.de

${ }^{1}$ Bavarian State Collection of Zoology - SNSB, Münchhausenstraße 21, 81247

Munich, Germany

${ }^{2}$ Ludwig-Maximilians-Universität München, Department Biologie II,

Großhaderner Straße 2, 82152, Planegg-Martinsried, Germany

Full list of author information is available at the end of the article
}

olfactory chemoreceptors, and mechanoreceptors) very much like the antennae of insects [5-11]. Furthermore, the trichobothria and slit sense organs on the walking legs (2nd - 4th pair of legs) are important sensory structures $[2,12]$.

As nocturnal animals most activity of whip spiders takes place in darkness, hence the visual system certainly plays a subordinate role in spatial orientation [5]. Nevertheless, whip spiders have two classes of eyes: one pair of larger elevated eyes on the frontal region of the central carapace commonly referred to as median eyes, and one pair of three smaller eyes further back on each side of the lateral carapace, commonly referred to as lateral eyes (see Fig. 1). Little is known about the detailed structure of these eyes $[2,13-15]$. The median eyes of whip spiders are formed from an invagination and are everted, hence the rhabdomeres point towards the light, and the nucleus lies basally [2, 15]. A tapetum, which reflects the incoming light towards the rhabdomeres, is 

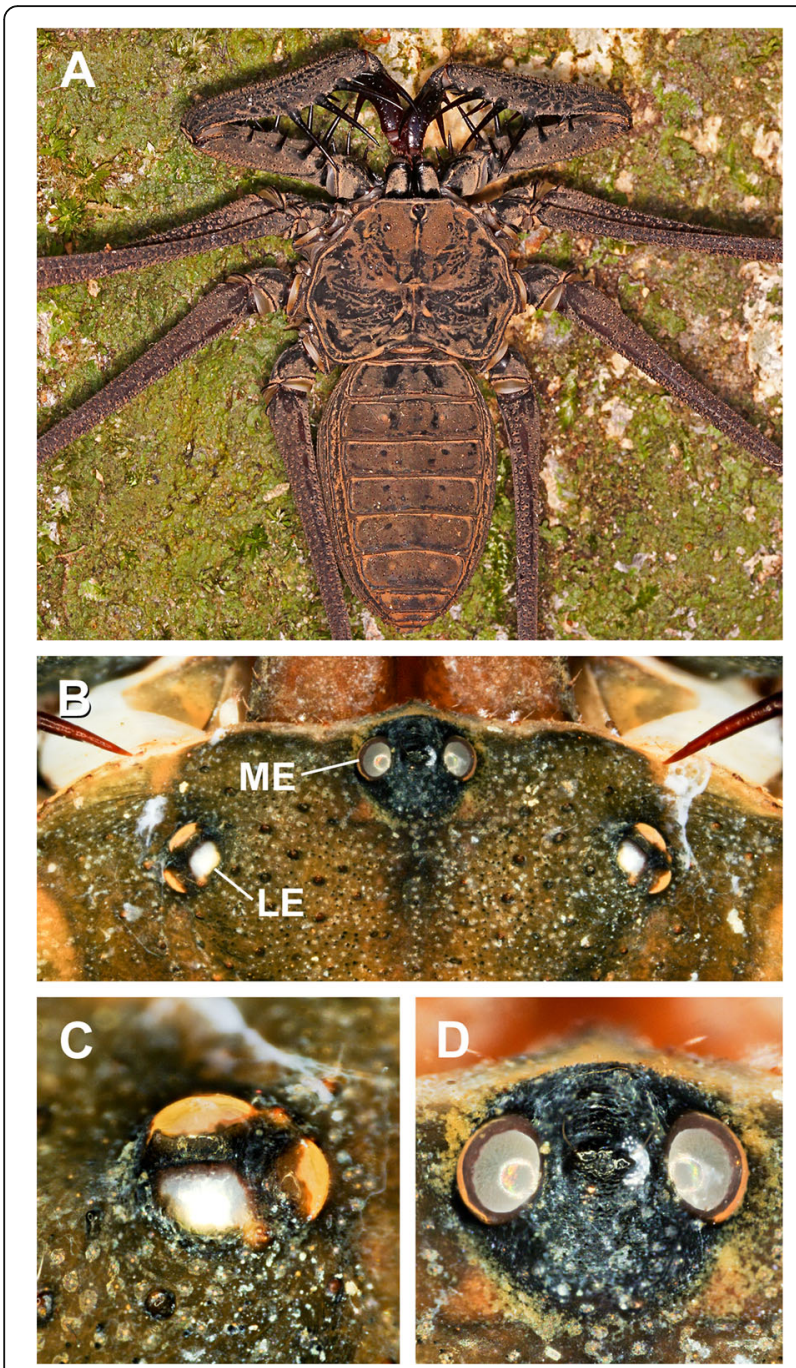

Fig. 1 Median and lateral eyes in Amblypygi. Heterophrynus elaphus (a), Damon medius (b-d). a, Whip spider in natural habitat. b, Anterior part of the cephalothorax with one pair of median eyes and three pairs of lateral eyes. $\mathbf{c}$, Detail of lateral eyes. $\mathbf{d}$, Detail of median eyes

absent. For instance in Phrynus marginemaculatus, there are slightly more than 100 R-cells (or retinula cells) per median eye [2]. The lateral eyes of whip spiders develop from a thickening of the epithelium without invagination. These eyes are of the inverted type, hence the rhabdomeres are located proximally and the nuclei distally to the incoming light $[2,15]$. The lateral eyes have a reflecting tapetum [2]. For instance, in P. marginemaculatus, there are about 75 R-cells per lateral eye [2].

The eyes probably measure light intensity and play a role in adjusting the circadian rhythm [2]. Whip spiders, for example, react to sudden illumination and find dark places in which to hide quickly [2]. Even less is known about the neuroanatomy of the visual systems. So far, the only studies on the visual neuropils are of Hanström [16], Weygoldt [2], and Wiegmann, et al. [6]. Hanström reported two successive median eye neuropils and one lateral eye neuropil in Neophrynus. Weygoldt tentatively noted two visual neuropils for both median and lateral eyes. Finally, Wiegmann et al. superficially demonstrate the presence of the higher order neuropils, mushroom bodies and arcuate body, but could not find distinct visual input.

Despite the problems in resolving the phylogenetic tree of Chelicerata (see the recent review by Giribet [17]), the relationships of Amblypygi seem to be clear. Together with Thelyphonida, Schizomida and Araneae they form the clade Tetrapulmonata (the orders typically with four lungs), well supported by molecular and morphological data [18-22]. However, the placement of Tetrapulmonata within the chelicerate tree is difficult. Modern molecular and novel morphological data support a relationship of Tetrapulmonata with Scorpiones forming the clade Arachnopulmonata - endorsed by the homology of the book lungs of scorpions with the lungs of tetrapulmonates [23-25]. One alternative theory is, e.g., a sister group relationship of Tetrapulmonata with Palpigradi $[19,21,26]$.

In order to fill the substantial knowledge gap on whip spider visual systems, and to find new morphological data to support or refute one of the current phylogenetic hypotheses, in the present paper we analyse the visual system of four amblypygid species (Heterophrynus elaphus, Damon medius, Phrynus marginemaculatus, and P. marginemaculatus). We used various neuroanatomical techniques (Cobalt fills, Wigglesworth stains, $\mu \mathrm{CT}$, and AMIRA-3D-reconstruction) to locate the target neuropils of the axon terminals of the R-cells and describe the number, form, connectivity and general morphology of the visual neuropils. Furthermore, the higher order neuropils arcuate body and mushroom bodies are described. These neuropils probably also play a role in the integration of visual information in chelicerates [27-29]. By now, the visual systems of several chelicerate orders have been studied [28-39]. Therefore, comparable morphological data on the visual systems of Pycnogonida, Xiphosura, Scorpiones, Pseudoscorpiones, and Opiliones is available and can be compared to our recent findings in Amblypygi.

\section{Results}

\section{General layout of the visual system and of the protocerebrum}

The visual system in the studied amblypygid species is composed of one pair of median eyes located medially on the front corner of the cephalothorax, and one pair of three lateral eyes located laterally on each side of the cephalothorax (Fig. 1). The nerve fibres project from the median and lateral eyes proximally to the lateral protocerebrum. 
The three lateral eyes are connected to two distinct, successive visual neuropils as targets of the R-cell axons (Fig. 2). The first lateral eye neuropil is located in a ventrolateral part of the protocerebrum, underneath the first visual neuropil of the median eyes (see below). It is oval and embedded in the cell body rind of the brain, and subdivided into three subunits, one for each lateral eye. The second neuropil lies posterior to the first neuropil in a central position of the protocerebrum. It is also subdivided into three subunits, one for each lateral eye (Fig. 2).

The two median eyes also supply two distinct, successive visual neuropils as targets of the R-cell axons
(Figs. 3, 4). The first neuropil is located in a dorsolateral part of the protocerebrum. The neuropil is spherical and embedded in the cell body rind of the brain. The second neuropil lies deeper, under the cell body rind and in a more ventral and posterior position in the protocerebrum. Furthermore, a few fibres leave the second median eye neuropil and end in the second lateral eye neuropil. Hence, axonal trajectories of the median and lateral eyes end in a shared region.

The visual neuropils are unequivocally identified with Cobalt fills, and also can be recognised with $\mu \mathrm{CT}$ scans and in Wigglesworth stains, as dark-stained areas, as is
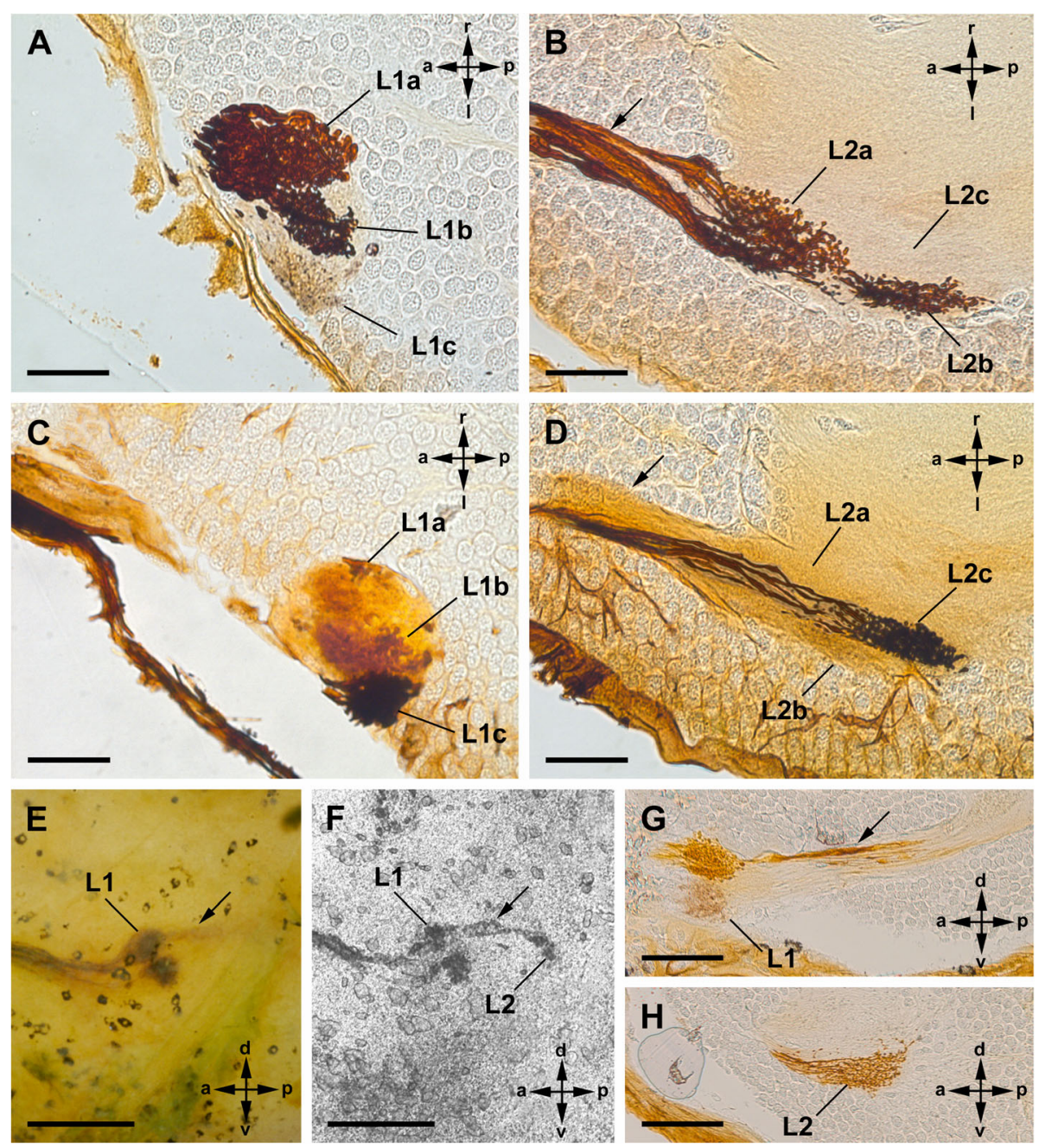

Fig. 2 Cobalt fills via lateral eyes in Amblypygi. Damon medius; frontal sections (a-d); sagittal view (e-h). a, b, Cobalt fills via two lateral eyes, accordingly two subunits (subunit $\mathbf{a}, \mathbf{b}$ ) of first (a) and second (b) visual neuropils are stained. Note dense arrangement with varicosities of Cobalt-filled profiles. In the tract between the first and second neuropil (arrow) it seems, that the fibres cross. Bars $50 \mu \mathrm{m}$. $\mathbf{c}$, d , Cobalt fills via one lateral eye (different eye than in $\mathbf{a}$, b), accordingly different subunit (subunit c) of the first (c) and second (d) visual neuropil are stained than in $\mathbf{a}, \mathbf{b}$. Bars $50 \mu \mathrm{mm}$. e-h, Comparison of whole mount, $\mu \mathrm{CT}$, and sections of same specimen. Two lateral eyes are filled with cobalt, hence two subunits of the first lateral eye visual neuropil are stained. Dorsally the first and second visual neuropil is stained with cobalt, but ventrally cobalt stopped in the first visual neuropil, and the second neuropil remained unstained. In whole mount (e; bar $250 \mu \mathrm{m}$ ) only the first visual neuropil is definitely visible. In $\mu \mathrm{CT}$ reconstruction (f; bar $250 \mu \mathrm{m}$ ) the first and second neuropil is visible. Most details become apparent in sections ( $\mathbf{g}, \mathbf{h}$; bars $100 \mu \mathrm{m}$ ). L1, first lateral eye neuropil; L2, second lateral eye neuropil; $\mathbf{a - c}$ subunits of L1 and L2; arrow, tract connecting L1 and L2 

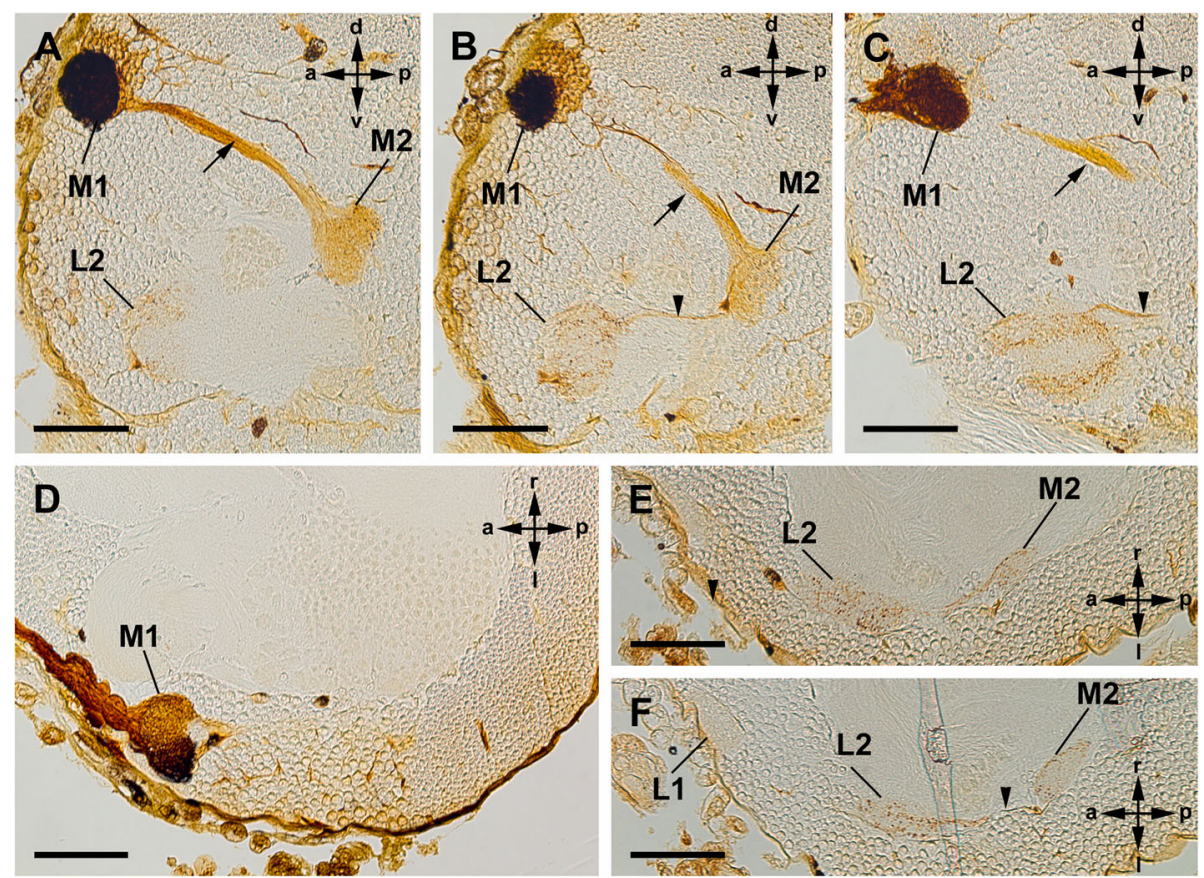

Fig. 3 Cobalt fills via median eyes in Amblypygi. Phrynus marginemaculatus; sagittal sections (a-c); frontal sections (d-f). a, b, Two consecutive sections of the same specimen. $\mathbf{a}$, First and second median eye visual neuropil filled with cobalt. Note dense arrangement of Cobalt-filled profiles in the first visual neuropil and just a few filled fibres running further to the second visual neuropil resulting in a diffuse staining of the neuropil. Both neuropils are connected via a tract (arrow). Bar $100 \mu \mathrm{m}$. b. First and second visual neuropil stained. Additionally, a thin tract connects the second median eye neuropil and the second lateral eye neuropil (arrowhead). A few cobalt filled R-cell axons run through this tract and terminate in the second lateral eye neuropil. Bar $100 \mu \mathrm{m}$. c, Same situation in a different specimen. Some cobalt filled R-cells from the median eye terminate in the second lateral eye visual neuropil. Bars $100 \mu \mathrm{m}$. d-f, Same situation in a third specimen and in frontal sections. Bars $100 \mu \mathrm{m}$. M1, first median eye visual neuropil; M2, second median eye visual neuropil; L1, first lateral eye neuropil; L2, second lateral eye neuropil; arrow, tract connecting M1 and M2; arrowhead thin tract connecting $\mathrm{M} 2$ and $\mathrm{L} 2$

typical for dense neuropils such as sensory neuropils (Figs. 5, 6).

Furthermore, the arcuate body is found in a posterior position in the ventral protocerebrum; its shape is slightly bent anteriorly. The mushroom bodies are located parallel to the midline on each side of the dorsal protocerebrum. Both neuropils can be recognised with Wigglesworth stains and $\mu \mathrm{CT}$ (Figs. 5, 6).

\section{Lateral eye visual neuropils}

Cobalt fills via the lateral eyes reveal two distinct retinula axon target regions in each hemisphere of the protocerebrum, a first and a second visual neuropil (Fig. 2).

After entering the first visual neuropil, the retinula axons build synaptic varicosities all over their extensions (Fig. 2a, c). The first visual neuropil is subdivided into three subunits. When three eyes are cobalt filled, all three subunits are stained. Accordingly, when two eyes are filled, two subunits are stained and one filled eye results in one stained subunit (Fig. 2a, c). A chiasma between the first and second visual neuropils is not positively identified in any of the chosen section planes (sagittal, frontal, or transversal) and in any method (cobalt fills, Wigglesworth stains, or $\mu \mathrm{CT}$ ). However, when seen from a frontal view, fibres of the three eyes are observed that seem to cross each other between the first and second visual neuropil, but it rather seems that the fibres from each eye are twisted and do not build a "classical" chiasma as in Tetraconata (Fig. 2b). In the second visual neuropil, the retinula axon terminals are branched and have synaptic varicosities (Figs. 2b, d, 4a, b, e, f). Here, also three subunits receiving the trajectories of one of the three eyes each are visible. As in the first neuropil, when three eyes are cobalt-filled, all three subunits are stained. Accordingly, when two eyes are filled two subunits are stained and one filled eye results in one stained subunit (Figs. 2b, d; 4a, f). Both visual neuropils are also visible in $\mu \mathrm{CT}$ and Wigglesworth stains (Figs. 5f, g; 6a, c, d, j, k). When comparing the results in D. medius and P. pseudoparvulus - the two species where cobalt fills via the lateral eyes were made - we found no species-specific differences. We also found no differences, when comparing the neuroanatomy of these two species with the Wigglesworth stains in H. elaphus. 

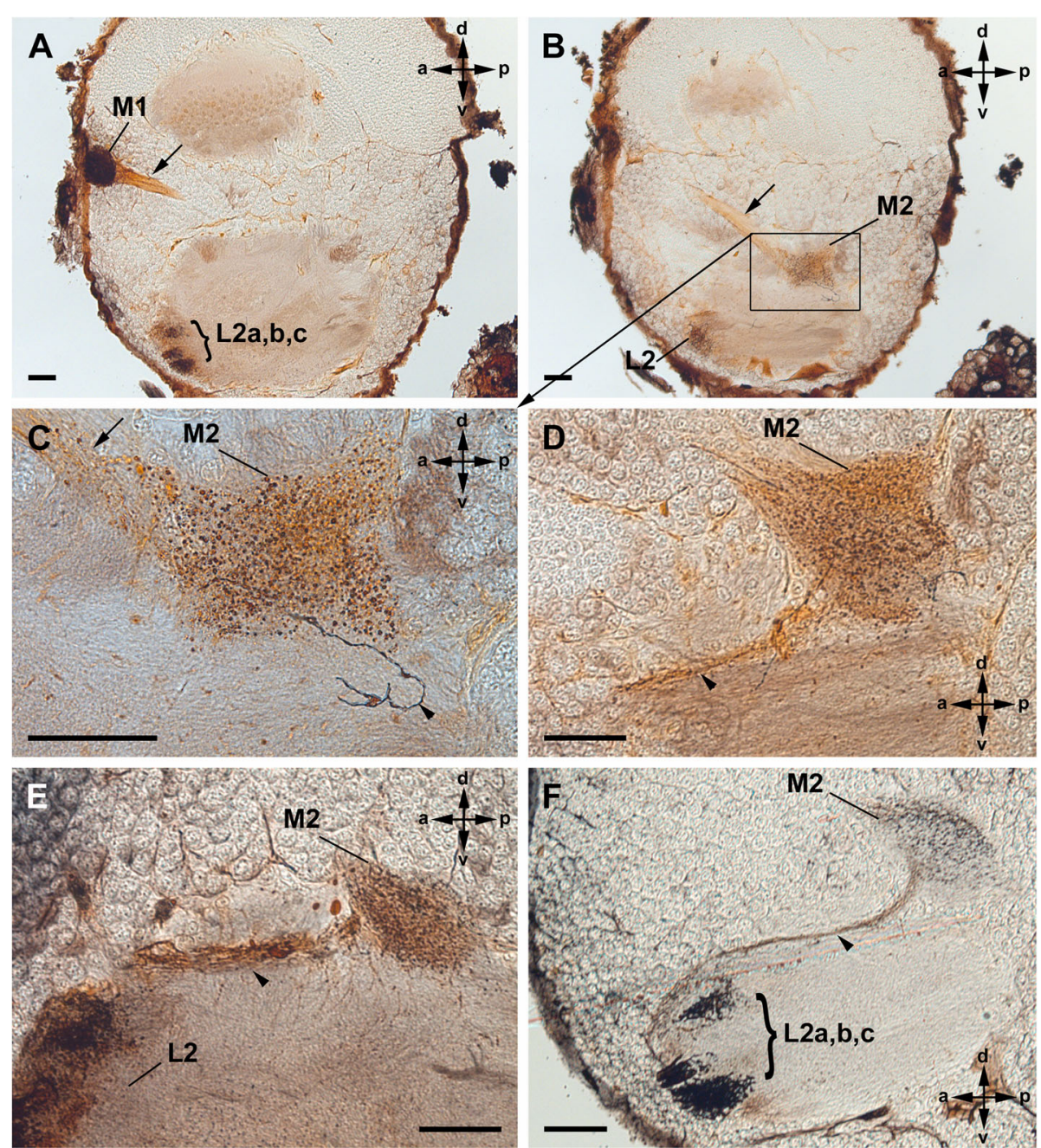

Fig. 4 Cobalt fills simultaneously via median and lateral eyes in Amblypygi. Phrynus pseudoparvulus; all eight eyes stained; sagittal sections. a-d, Three consecutive sections of the same specimen; $\mathbf{c}$ detail of $\mathbf{b}$. Cobalt visible in (I) the first median eye visual neuropil, (II) the tract between first and second median eye neuropil (arrows), (III) the second median eye visual neuropil, (IV) a thin tract between the second median eye and second lateral eye visual neuropil (arrowheads), ( $V$ the second lateral eye neuropil, (VI) the tract between the first and second median eye neuropil (not shown, but available on morph-d-base) and (VII) the first lateral eye neuropil (not shown, but available on morph-d-base). Note U-turn of a few fibres (arrowheads) from the second median eye neuropil to a thin tract connecting the second median and second lateral eye neuropil. Bars $50 \mu \mathrm{mm}$. e, f, Different specimens showing details of the connection between the second median and second lateral eye neuropil via a thin tract (arrowhead). Bars $50 \mu \mathrm{m}$. M1, first median eye visual neuropil; M2, second median eye visual neuropil; L2, second lateral eye neuropil; arrow, tract connecting M1 and M2; a-c subunits of $\mathrm{L} 2$; arrowhead thin tract connecting $\mathrm{M} 2$ and $\mathrm{L} 2$

\section{Median eye visual neuropils}

Cobalt fills via the median eyes revealed three distinct retinula axon target regions in each hemisphere of the protocerebrum: the first and second median eye visual neuropil, and additionally a few R-cell axons even reach to the second lateral eye neuropil (Figs. 3 and 4).

Immediately after entering the brain, the retinula axons build synaptic varicosities in a crescent-shaped region of the first visual neuropil (Figs. 3a-d, f; 4a). This region is also visible in Wigglesworth stains as darker stained region and in $\mu \mathrm{CT}$ scans (Figs. 5c, d; 6a, b, h-k). Proximal to the crescent-shaped region the visual fibres are concentrated and the retinula axons project ventro-posteriorly in a tract through the cell body rind deeper into the protocerebrum (Figs. 3a-c; 4a-c; 5c, e; $6 \mathrm{~d}, \mathrm{~h}$ ). Again, a chiasma between the first and second visual neuropils is not positively identified. Most of these fibres end in the second median eye visual neuropil. In the cobalt fills, only a diffuse staining and a few slightly darkened fibres are visible, indicating that only a few R-cell axons terminate in the second visual neuropil (Figs. 3a, b, e, f; 4b-f). The second median eye visual neuropil is also visible in $\mu \mathrm{CT}$ scans and Wigglesworth stains (Figs. 5c, e; 6d, i, j). Even fewer fibres 

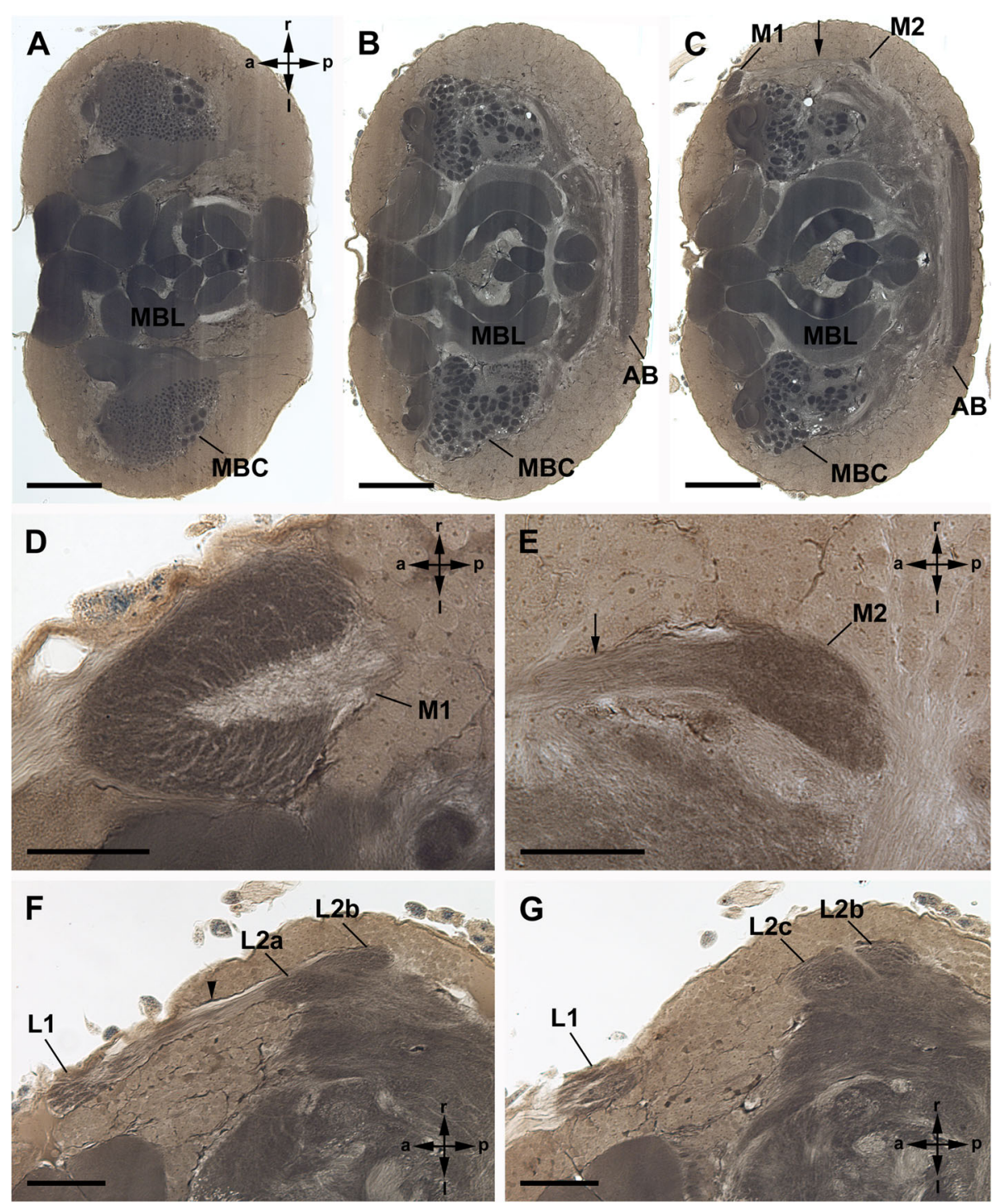

Fig. 5 General anatomy of visual neuropils and protocerebrum in Amblypygi, frontal sections. Heterophrynus elaphus; Wigglesworth stains. a-c, Three sections from dorsal (a), central (b) and more ventral (c) part of the protocerebrum showing large-scale spread of the mushroom bodies, especially of the mushroom body lobes. Note the relatively small arcuate body. Bars $250 \mu \mathrm{m}$. d, e, Detail of the first and second median eye visual neuropil. Bars $50 \mu \mathrm{m} . \mathbf{f}, \mathbf{g}$. Detail of the first and second lateral eye visual neuropil. Note subdivision of the second visual neuropil into three subunits. Bars 100 mm. AB, arcuate body; MBC, mushroom body calyces; MBL, mushroom body lobes; M1, first median eye visual neuropil; M2, second median eye visual neuropil; L1, first lateral eye neuropil; L2, second lateral eye neuropil; arrow, tract connecting M1 and M2; a-c subunits of L2; arrowhead tract connecting L1 and L2

leave the second neuropil and point in a thin tract anteriorly and terminate in the second lateral eye neuropil (Figs. 3b, c, e, f; 4c-f). Again, in the cobalt fills, only a diffuse staining and a few slightly darkened fibres are visible, indicating that only a few $\mathrm{R}$-cell axons are stained. The cobalt filled R-cells from the median eyes are found throughout the whole second lateral eye neuropil (Figs. 3b, c, e, f). The thin tract that connects the second median and second lateral eye visual neuropil is only visible in cobalt fills and not in $\mu \mathrm{CT}$ scans and Wigglesworth stains. As in the lateral eyes, we found no species-specific differences between the studied species ( $P$. pseudoparvulus, P. marginemaculatus, and $H$. elaphus).

\section{Arcuate body}

The arcuate body is rather small (Figs. 5b, c; 6e-g). It is found in a more ventral position of the posterior protocerebrum. The arcuate body is composed of two layers and slightly bent anteriorly. A direct visual input of R-cells is not observed. However, tracts from the 

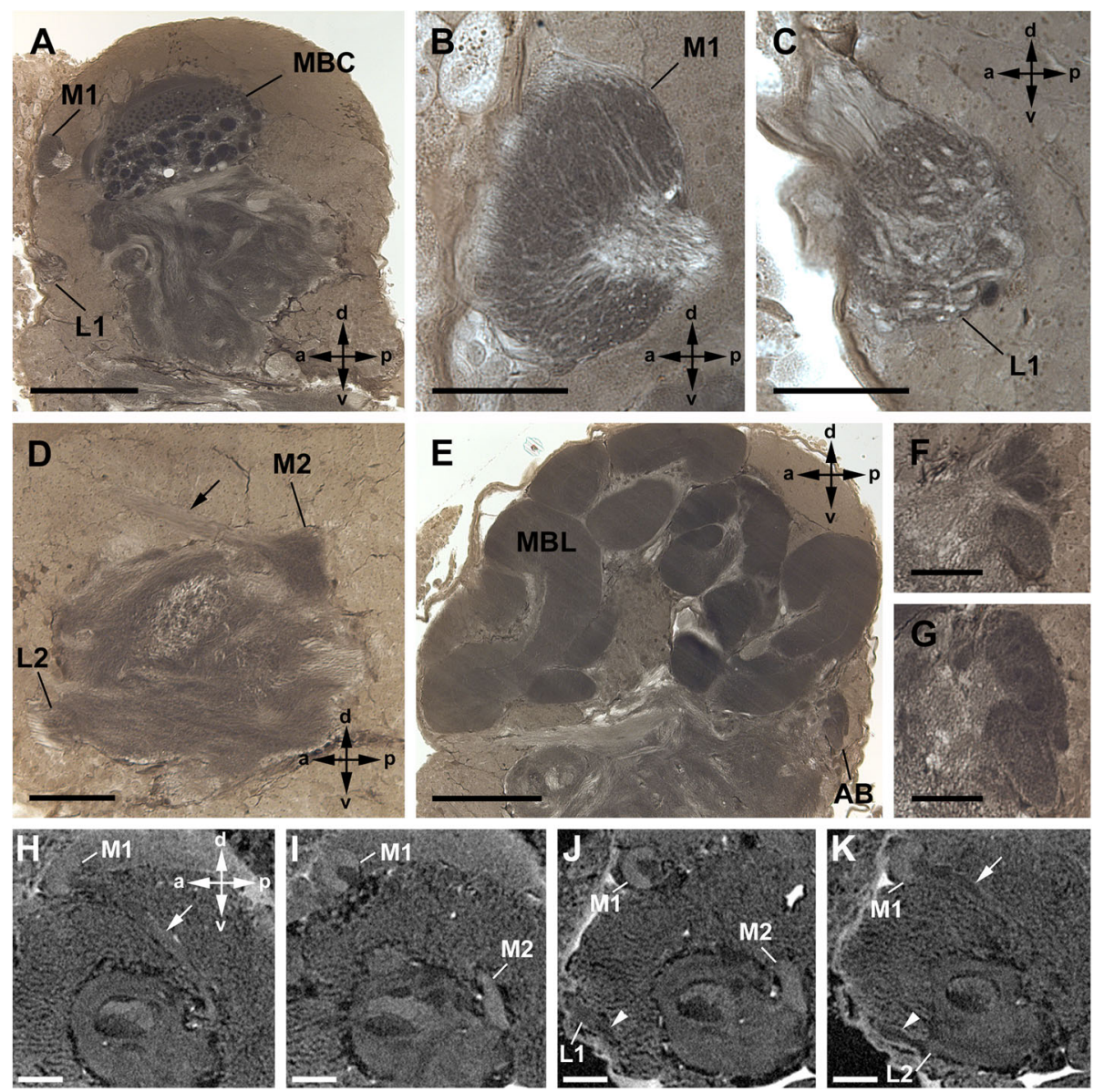

Fig. 6 General anatomy of visual neuropils and protocerebrum in Amblypygi, sagittal sections. Heterophrynus elaphus (a-g) and Damon medius (h-k); Wigglesworth stains (a-g) and $\mu \mathrm{CT}$ (h-k, additional raw data on morph-D-base). $\mathbf{a}$, Dorsal to the first median eye visual neuropil lies the first lateral eye neuropil. Bar $250 \mu \mathrm{m}$. b, c, Detail of the first median and lateral eye visual neuropil. Bars $50 \mu \mathrm{m}$. $\mathbf{d}$, Section showing a tract connecting the first and second median eye neuropil, the second median eye neuropil, and the second lateral eye neuropil. Bar $100 \mu \mathrm{m}$. E, Mid-sagittal section showing the mushroom body lobes filling almost the entire protocerebrum. Note the relatively small arcuate body. Bar $250 \mu m$. $\mathbf{f}, \mathbf{g}$,

Detail of the arcuate body in parasagittal (f) and midsagittal $(\mathbf{g})$ region. Bars $50 \mu \mathrm{m} . \mathbf{h}, \mathbf{i}, \mu C T$ reconstruction showing the first and second median eye visual neuropil and a tract (arrow) connecting these two neuropils. Bars $250 \mu \mathrm{m}$. j, $\mathbf{k}, \mu \mathrm{CT}$ reconstruction showing the first and second lateral eye visual neuropil and a tract (arrow) connecting these two neuropils. Bars $250 \mu \mathrm{m}$. AB, arcuate body; MBC, mushroom body calyces; MBL, mushroom body lobes; M1, first median eye visual neuropil; M2, second median eye visual neuropil; L1, first lateral eye neuropil; L2, second lateral eye neuropil; arrow, tract connecting M1 and M2; arrowhead tract connecting L1 and L2

second lateral and second median eye neuropils seem to point towards the arcuate body.

\section{Mushroom bodies}

The mushroom bodies are exceptionally large (Figs. 5a-c; $6 \mathrm{a}, \mathrm{e})$. Altogether, the mushroom body allocates about two-thirds of the neuropil of the protocerebrum. The mushroom body lobes are folded several times (Figs. $5 a-c, 6 e)$. In the midsagittal region, the lobes occupy almost the whole protocerebrum (Figs. 5a-c, 6e). The mushroom body calyces are also large. They are subdivided into glomeruli of two different kinds (Figs. 5a-c, 6a). Dorsally one-third of the calyces consist of small glomeruli (diameter 5-9 $\mu \mathrm{m}$ ) and laterally two-thirds of the calyces of large glomeruli (diameter $20-30 \mu \mathrm{m})$. A direct (R-cells) or indirect (tracts from the visual neuropils) visual input is not observed.

\section{Discussion}

\section{Comparison with previous literature}

So far, the only studies concerning the visual neuropils of Amblypygi were published by Hanström [16], Weygoldt [2], and Wiegmann, et al. [6]. Comparing the present results with the remarkable study of Hanström, one finds many accordances, but also some discrepancies. He studied the visual neuropils of the whip spider Neophrynus sp.. For the median eyes, he reported a first large neuropil ("Sehmasse") in the peripheral part of the brain and a less 
distinct second neuropil at the edge of the neuropil mass. This reflects our results very well. However, the few median eye R-cell fibres that leave the second median eye neuropil and terminate in the second lateral eye neuropil are not mentioned by Hanström. For the lateral eyes, he described one shared neuropil only. We showed clearly that the lateral eyes also have two successive visual neuropils. Furthermore, he characterised as we did a small arcuate body and giant mushroom bodies. Weygoldt [2] just mentioned briefly two visual neuropils ("optic masses") for each median eye and for each lateral eye group. However, his statements are without further illustrations, what makes it difficult for comparison. Finally, Wiegmann, et al. [6] looked for visual input into higher order neuropils and stated that there is no visual input into the mushroom bodies or arcuate body.

In the present study, we unequivocally identified for the first time the R-cell terminals of the median and lateral eyes of whip spiders by using cobalt as a precise marker, a tool Hanström did not have at that time. From this, the visual neuropils are characterized. Furthermore, we describe the general neuroanatomy of the protocerebrum based on classical histology and $\mu \mathrm{CT}$.

Our main findings are: (I) The R-cells of the lateral eyes are connected to a first and a second lateral eye visual neuropil. Both neuropils are subdivided into three subunits, one for each lateral eye. (II) The R-cells of the median eyes are connected to a first and a second median eye visual neuropil. Furthermore, (III) a few median eye R-cell fibres leave the second median eye neuropil and terminate in the second lateral eye neuropil. This means that some R-cells from the median eyes and from the lateral eyes terminate in a shared region, i.e. the second lateral eye visual neuropil. (IV) The two-layered arcuate body is relatively small compared to (V) the giant mushroom bodies. These are composed of several times folded mushroom body lobes and mushroom body calyces with two different kinds of glomeruli (small and large ones).

When interpreting the results we must consider what kind of neuropil the second lateral eye neuropil might be. With a few R-cells from the median eyes terminating herein, is it possible that it is a median eye neuropil as well? Alternatively, could it even be a higher order neuropil or "pre-integration centre" where information from both eye types is interconnected? Our interpretation is that it is a lateral eye neuropil, because the vast majority of the input comes from the lateral eyes, and just a few fibres come from the median eye. One possible function of this interconnection from both eye types could be lateral inhibition [40].

Furthermore, it deserves mention here that we found no species-specific differences in the four studied species. This corresponds to the general assumption that the nervous system displays a high degree of conservatism. This, in turn, makes comparative studies on the structure and development of the nervous systems suitable for higher-level phylogenetic analysis, e.g. the phylogeny of the chelicerate orders. For this field of research two different approaches - "neurophylogeny" [41-43] and "neural cladistics" [44, 45] - were established.

\section{Comparison with other chelicerates}

The features described in the present study allow a comparison with the visual systems in other chelicerates. In all studied chelicerate visual systems, for both median eyes and lateral eyes, one constant feature appeared two successive visual neuropils with direct input from the eyes via R-cell terminals [30, 32, 33, 35, 38, 39]. However, the only exception is Araneae (spiders). Here, for both eye types, just the first visual neuropils receive direct input and in the second neuropils, no R-cell terminals are found $[28,29]$.

Hence, in the forefront of this study, the question arose, if whip spiders, follow the rule of two neuropils and do they have short and long R-cell fibres as, e.g., horseshoe crabs, scorpions, harvestmen, and pseudoscorpions, or just short fibres, as described for the spider Cupiennius salei?

As shown above, it became apparent, that amblypygids do not merely have for both - median eyes and lateral eyes - two successive visual neuropils with direct R-cell input, but also show striking similarities with horseshoe crabs and scorpions (Fig. 7). In all three chelicerate orders - Xiphosura, Scorpiones, and Amblypygi - R-cell fibres from the median eyes terminate in the second lateral eye neuropil. This means that in all three, there is a region where median and lateral eye R-cell terminals overlap.

In the lateral rudimentary eyes (not the lateral compound eyes) of the horseshoe crab (Limulus polyphe$m u s)$, the R-cells terminate in the first and second lateral eye neuropil (Fig. $7 \mathrm{~g}$ ). In the median eyes (not the median rudimentary eyes), the photoreceptor cells terminate in the first median eye visual neuropil and the arhabdomeric cells (non-photosensitive, secondary neurons in the retina) terminate in a second median eye neuropil that partly overlaps with the second lateral eye neuropil (Fig. 7f) [36-39, 46]. Hence, there is a region, where R-cell terminals of median and lateral eyes overlap (see discussion in Lehmann and Melzer [33]). In scorpions, the second visual neuropils overlap as well, or rather the R-cell fibres from the median (also the arhabdomeric cells) and from the lateral eyes (Fig. 7d). Lehmann, et al. [33] already discussed the close evolutionary relationships of the visual systems in Scorpiones and Xiphosura (median eyes and lateral rudimentary eyes).

Although they are less numerous, than, e.g., in scorpions, we also found in whip spiders R-cell fibres 

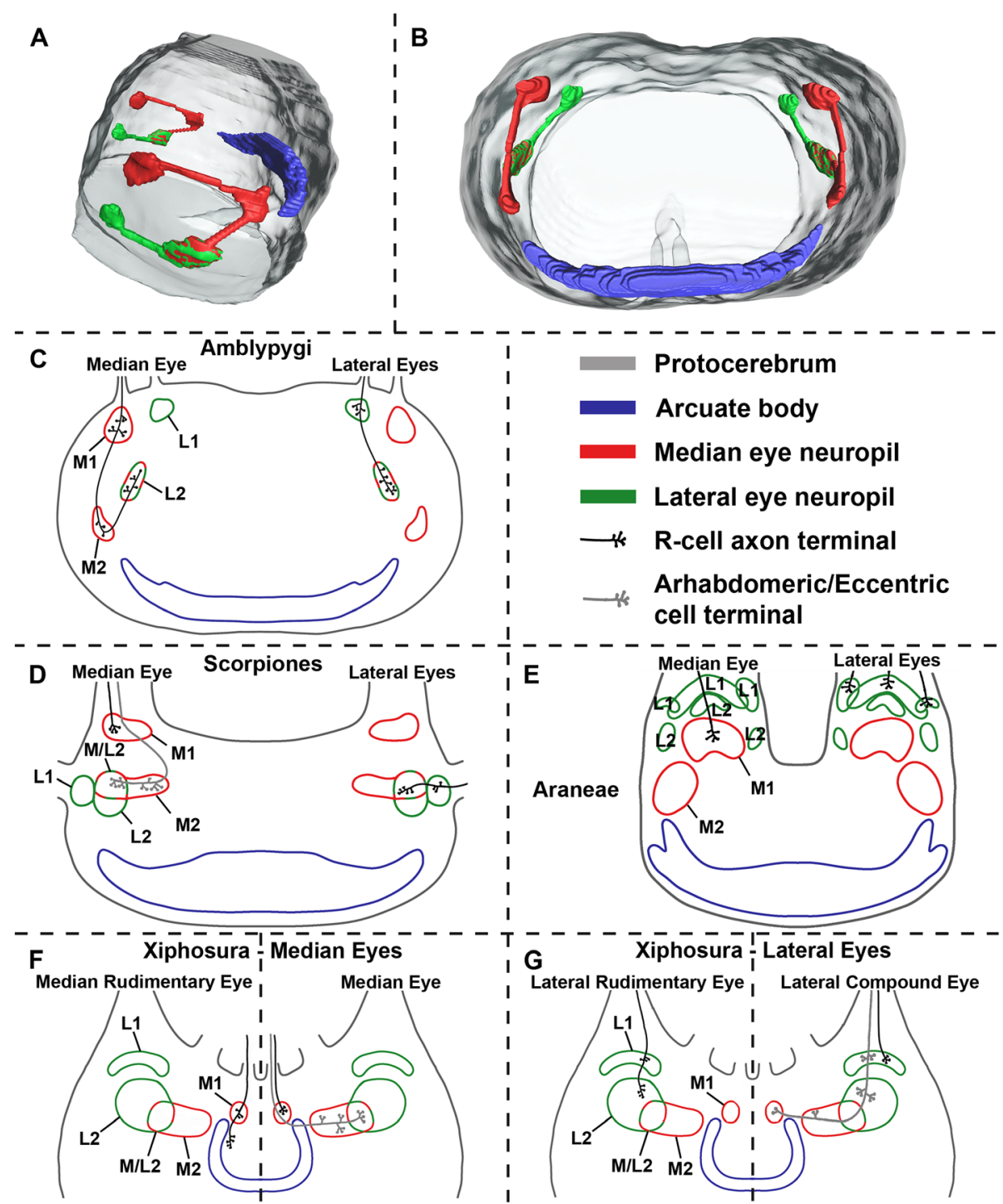

Fig. 7 Comparison of median and lateral eye visual systems in (c) Amblypygi, (d) Scorpiones, (e) Araneae, and (f, g) Xiphosura. a, b, 3D serial reconstruction of the visual system of whip spider Heterophrynus elaphus. c, Amblypygi (Damon medius, Heterophrynus elaphus, Phrynus spp.), this study. d, Scorpiones (Euscorpius spp., Androctonus australis), after Lehmann, et al. [33] and Fleissner [40]. e, Araneae (Cupiennius salei), after Strausfeld, et al. [28], Strausfeld, et al. [29]. f, g, Xiphosura (Limulus polyphemus), after Lehmann, et al. [33], Calman, et al. [38], Chamberlain, et al. [39]. L1, first lateral eye visual neuropil; L2, second lateral eye visual neuropil; M1, first median eye visual neuropil; M2, second median eye visual neuropil; M/L2, region were M1 and L1 overlap

from the median eyes, that terminate in the second lateral eye neuropil (Fig. 7c). One difference is that in the studied amblypygid species, these fibres are found throughout the whole second lateral eye neuropil and not - as in Limulus and scorpions - in a part of the neuropil. Furthermore, for Limulus and scorpions, it seems that the second median and lateral eye neuropils overlap. This is not the case in whip spiders. Here the second visual neuropils are connected via a thin tract, where the median eye R-cells run through.

One question that emerges concerns the nature of these fibres from the median eyes that terminate in the second lateral eye neuropil. In Limulus and scorpions, these long, overlapping fibres are from the arhabdomeric cells. So far, only one detailed TEM-study on the eyes of Thelyphonida (whip scorpions), the sister taxon of Amblypygi exists [47]. The structure of the eyes of Amblypygi and Thelyphonida seem to be similar [2, 47]. Meyer-Rochow [47] described arhabdomeric cells for both median and lateral eyes in the whip scorpion Thelyphonus caudatus but had difficulties to determine their exact location and number. Hence, if whip spiders also possess arhabdomeric cells, it is possible, that these fibres could have their origin in the arhabdomeric cells. However, further investigation on the arhabdomeric 
cells in whip spiders and on the visual neuropils of whip scorpions is needed.

The other arachnid orders differ. In Araneae - the only other studied arachnid order with both median and lateral eyes (some mites (Acariformes) do also have both eye types) - different numbers of visual neuropils are reported in different spider species [16, 28, 29, 48, 49]. For the median eyes (principal eyes or anterior median eyes), a first and a second visual neuropil are always described. However, for the lateral eyes (secondary eyes) the situation differs. Generally speaking, for most web-spinning spiders (e.g., Araneidae, Deinopidae, Pholcidae) only one lateral eye neuropil and for free living or active hunting spiders (e.g., Ctenidae, Salticidae, Lycosidae) two (first and second) lateral eye neuropils are reported [16, 49, 50]. In Cupiennius - the best studied spider species - the R-cells from the median and lateral eyes terminate in the first median and the first lateral eye visual neuropil, respectively, and no long R-cell fibres to the second visual neuropils are described (Fig. 7e) [40, 41]. In Opiliones and Pseudoscorpiones, having either median or lateral eyes, this overlapping naturally cannot be found $[16,32,35,51,52]$.

\section{Conclusions}

Before we started our series of studies about the visual systems in various chelicerates [30-35], of which the present one is the most recent, the number of visual neuropils seemed to be inconsistent. Thus, e.g., in scorpions one neuropil was described for the median eyes and three for the lateral eyes [16], in harvestmen, which have just median eyes, three neuropils [51], in pseudoscorpions, which have just lateral eyes, one neuropil $[16,53]$, and in whip spiders two for the median eyes and either one or two for the lateral eyes $[2,16]$. Furthermore, in Pycnogonida two visual neuropils were reported, but the suggested second order neuropil was displaced into a different position [54]. Conversely, it now becomes apparent that in all chelicerate visual systems, we studied until now, regardless of whether median eyes or lateral eyes, one constant feature appeared - two successive visual neuropils [28-30, $32,33,35,38-40]$. This type of architecture is well known from other arthropods, e.g. from Myriapoda (having just lateral eyes) $[55,56]$ and from the lateral eyes in Tetraconata (crustaceans and insects) (reviewed, e.g., in [57-59]), and might be plesiomorphic for the euarthropod main lineages. According to Tanaka, et al. [60] even in fossil Megacheira (great appendage arthropods) - which strongly resemble early chelicerates - two successive visual neuropils are found. Furthermore, at the current state of our survey, in all chelicerate orders, the first and the second order neuropils receive direct input from the eyes via R-cell terminals - with one exception, Araneae.

The phylogenetic interpretation of these findings is difficult. Are the similarities of the visual systems between
Xiphosura, Scorpiones, and Amblypygi just functionally caused, conditioned by the fact that they all have median and lateral eyes, or are they also a phylogenetic signal for the suggested clade Arachnopulmonata - consisting of Araneae, Amblypygi, Thelyphonida and Scorpiones [25]? To formulate it cautiously our findings are certainly no counterevidence against close relationships between these four lineages. However, more research on the central projections of the R-cells and the visual neuropils in Thelyphonida and Araneae is necessary.

Why does Araneae not fit into the concept? Spiders also have median and lateral eyes and their sister group relationships to Amblypygi and Thelyphonida forming together the clade Tetrapulmonata seems to be clear [18-22], but their neuroanatomy seems to be a bit confused. For the lateral eyes, only one or two neuropils are reported and for both eyes types, just fibres terminating in the first visual neuropils are proven $[16,28,29,49]$. One explanation would lie in the methodology. Probably, the second lateral eye neuropil was overlooked in the histological sections of these studies and would be only visible in TEM, as in Pseudoscorpiones or Opiliones [32, 35]. Concerning the R-cell projections, Hanström [16] used osmium stains and Strausfeld, et al. $[28,29]$ Golgi impregnation and Reduced silver staining. Hence, for them it was probably not possible to study the exact projection of the R-cells. On that account, unequivocal tracers like the cobalt fills used in this study should be applied in spiders. Another explanation for the differences in the neuroanatomy could be that in the evolution of the visual system of this mega-diverse order some reductions took place. Probably, in the web spinning spiders the visual system became less important, what might have resulted in the reduction of the second lateral eye neuropil. Finally, in spiders arhabdomeric cells are not known. Arhabdomeric cells typically bear distal dendrites that contact R-cells and, therefore, they are considered to play a role as secondary neurons in the processing of visual information. So far, only photoreceptor cells and non-pigmented supportive cells or glia, but no arhabdomeric cells are described from the retina of spiders (see, e.g., [61$66])$. Hence, a connection from the arhabdomeric cells to the second visual neuropil - as in horseshoe crabs, scorpions, and whip spiders - would be missing.

\section{Material \& Methods}

\section{Animals}

Specimens of Heterophrynus elaphus Pocock, 1903 were collected during a field trip to the Private Protected Area ACP Panguana in Peru (collecting permit \#007-2014-SERFOR-DGGSPFFS, export permit \# 0001757-SERFOR). Specimens of Damon medius (Herbst, 1797) and Phrynus marginemaculatus Koch, 1841 were obtained from bugzuk. com. Specimens of Phrynus pseudoparvulus Armas \& Viquez, 2001 were obtained from vogelspinnen-kauf.de. 


\section{Cobalt fills}

Modified after Altman, et al. [67]: Specimens (overall 38 specimens, therefrom 22 successfully stained: Damon medius, median or lateral eyes filled, $n=13$, Phrynus pseudoparvulus, median and lateral eyes filled simultaneously, $n=6$; and Phrynus marginemaculatus, median eyes filled, $n=3$ ) were anaesthetized by using $\mathrm{CO}_{2}$. $\mathrm{CoCl}_{2}$ crystals were inserted into the median, lateral, or median and lateral eyes with a fine tungsten needle. After diffusion times between 5 and $22 \mathrm{~h}$, cobalt was precipitated with a solution of five drops of $\left(\mathrm{NH}_{4}\right)_{2} \mathrm{~S}$ in $10 \mathrm{ml} \mathrm{H}_{2} \mathrm{O}_{\text {dest. }}$. After fixation of the cephalothorax in

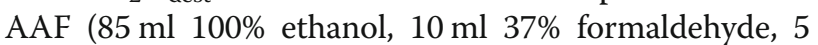
$\mathrm{ml}$ glacial acetic acid), the brain was dissected. The brain was silver intensified as follows: $60 \mathrm{~min}$ at $50^{\circ} \mathrm{C}$ in the dark in solution A $\left(10 \mathrm{ml} \mathrm{H}_{2} \mathrm{O}_{\text {dest }}, 3 \mathrm{ml} 100 \%\right.$ ethanol, $0.5 \mathrm{~g}$ gum arabic, and $0.02 \mathrm{~g}$ hydroquinone; $\mathrm{pH}$ value adjusted to between 2.6 and 2.8 using citric acid), and $20-40 \mathrm{~min}$ at $50^{\circ} \mathrm{C}$ in the dark in solution $\mathrm{B}(10 \mathrm{ml}$ $\mathrm{H}_{2} \mathrm{O}_{\text {dest }}, 3 \mathrm{ml} 100 \%$ ethanol, $0.5 \mathrm{~g}$ gum arabic, $0.02 \mathrm{~g}$ hydroquinone, $0.01 \mathrm{~g} \mathrm{AgNO}_{3} ; \mathrm{pH}$ value adjusted to between 2.6 and 3.1 using citric acid). Silver intensification was stopped in an acetic acid solution $(50 \mathrm{ml} 30 \%$ ethanol, $5 \mathrm{~g}$ glucose, $\mathrm{pH}$ value adjusted to between 2.6 and 3.1 using acetic acid). After dehydration in a graded acetone series, the specimens were embedded in Glycidether 100 , and sectioned with a rotary microtome and stainless steel blade in the sagittal and frontal planes $(14-16 \mu \mathrm{m})$. Finally, some sections were silver intensified in solution $\mathrm{A}$ and $\mathrm{B}$ for a second time.

\section{Wigglesworth stains (osmium-ethyl-gallate procedure)}

Modified after Wigglesworth [68], Leise, et al. [69], Mizunami, et al. [70]: Specimens (Heterophrynus elaphus, $n=6)$ were anaesthetized by using $\mathrm{CO}_{2}$ followed by decapitation. Brains were dissected and fixed overnight in $4 \%$ glutardialdehyde in $0.1 \mathrm{M}$ cacodylate buffer at $4{ }^{\circ} \mathrm{C}$. After postfixation in $1 \% \mathrm{OsO}_{4}$ in $0.1 \mathrm{M}$ cacodylate buffer $\left(2 \mathrm{~h}\right.$ at $\left.4{ }^{\circ} \mathrm{C}\right)$ animals were stained for $20 \mathrm{~h}$ at $4{ }^{\circ} \mathrm{C}$ in a saturated ethyl gallate solution, dehydrated in a graded acetone series, embedded in Glycidether 100, and sectioned with a rotary microtome and stainless steel blade in the sagittal and frontal planes $(10-12 \mu \mathrm{m})$.

\section{$\mu \mathrm{CT}$}

We tried, for the first time, to find out whether or not Cobalt fills can be seen in the $\mu \mathrm{CT}$. The $\mu \mathrm{CT}$ reconstruction is compared to whole mounts and sections and thus provides another line of evidence complementing the results from histological sections. The results are shown in Fig. 2.

Modified after Sombke, et al. [71]: Micro-CT scanning of the brain without cobalt fills (Damon medius, $n=2$ ): Specimens were anaesthetized by using $\mathrm{CO}_{2}$ followed by decapitation. Brains were dissected and fixed overnight in $4 \%$ formaldehyde in phosphate buffer (Roti ${ }^{\ominus}$-Histofix 4\%, Carl Roth GmbH + Co. KG, Germany) and dehydrated in a graded ethanol series. After incubation in $1 \%$ iodine solution in 100\% ethanol for $48 \mathrm{~h}$ and several washing steps in $100 \%$ ethanol, the brains were critical-point-dried.

Micro-CT scanning of the brain with cobalt fills (Damon medius, $n=1$ ): Cobalt filled brain (see above) was stored and scanned in 30\% ethanol.

Scanning was performed with a Phoenix Nanotom M (GE Measurement \& Control, Wunstorf, Germany) cone beam CT scanner at a voltage of $90 \mathrm{kV}$ and a current of $170 \mathrm{~mA}$ (critical point dried brain without cobalt fills, voxel size $1,58 \mu \mathrm{m}$ ) or $100 \mathrm{kV}$ and $120 \mathrm{~mA}$ (cobalt filled brain in $30 \%$ ethanol, voxel size $1,82 \mu \mathrm{m}$ ), using a standard target. 1440 projections were prepared per scan. The $3 \mathrm{D}$ datasets (prepared with the datos $\mid \mathrm{x}$ reconstruction software, GE Measurement \& Control) were examined by VGStudioMax 2.2 (Visual Graphics GmbH, Heidelberg, Germany) software.

\section{D-reconstruction}

The specimen (Heterophrynus elaphus, prepared as for Wigglesworth stains) was cut into a complete transversal series $(12 \mu \mathrm{m})$. Slices were mounted on glass slides, covered with cover-slips, and photographed under a conventional light microscope. Images were contrast-enhanced in Adobe Photoshop, then aligned, segmented and rendered in Amira.

\section{Acknowledgements}

We want to thank Dr. Juliane Diller and Erich Diller for the kind invitation to Panguana (Peru), David Hauth, Stefan Friedrich, and Ernst-Gerhard Burmeister for help with collecting the animals (H. elaphus). Furthermore, we want to thank the Servicio Nacional Forestal y de Fauna Silvestre (SERFOR) for issuing collecting (\# 007-2014-SERFOR-DGGSPFFS) and export (\# 0001757-SERFOR) permit and Dr. Diana Silva Dávila (Museo de Historia Natural, Universidad Nacional Mayor de San Marcos, Lima, Peru) for cooperation.

\section{Funding}

This study was supported by the Deutsche Forschungsgemeinschaft (DFG LE $3575 / 2-1)$.

\section{Availability of data and materials}

Additional raw data will be uploaded to Morph.D.Base. We will also provide original data upon request. The requesting party will need to supply a hard drive.

\section{Authors' contributions}

$\mathrm{TL}$ conceived the study, carried out the morphological analysis $\left(\mathrm{CoCl}_{2}\right.$, Wigglesworth, $\mu \mathrm{CT}$ ), and drafted the manuscript. RRM carried out some morphological analysis $(\mu \mathrm{CT})$ and helped in drafting the manuscript. Both authors read and approved the final manuscript.

Ethics approval and consent to participate Not applicable.

Consent for publication

Not applicable.

Competing interests

The authors declare that they have no competing interests. 


\section{Publisher's Note}

Springer Nature remains neutral with regard to jurisdictional claims in published maps and institutional affiliations.

\section{Author details}

'Bavarian State Collection of Zoology - SNSB, Münchhausenstraße 21, 81247 Munich, Germany. ${ }^{2}$ Ludwig-Maximilians-Universität München, Department Biologie II, Großhaderner Straße 2, 82152, Planegg-Martinsried, Germany. ${ }^{3}$ GeoBioCenter LMU, Richard -Wagner-Str. 10, 80333 Munich, Germany.

Received: 1 August 2018 Accepted: 5 November 2018 Published online: 19 December 2018

\section{References}

1. Whip spiders of the World, version 1.0. Western Australian Museum, Perth. http://museum.wa.gov.au/catalogues-beta/whip-spiders

2. Weygoldt P. Whip spiders (Chelicerata, Amblypygi). Stenstrup: Apollo Books; 2000

3. Dunlop JA. Systematics of the coal measures whip spiders (Arachnida: Amblypygi). Zool Anz. 2018;273:14-22.

4. Dunlop JA. Geological history and phylogeny of Chelicerata. Arthropod Struct Dev. 2010;39:124-42.

5. Bingman VP, Graving JM, Hebets EA, Wiegmann DD: Importance of the antenniform legs, but not vision, for homing by the neotropical whip spider, Paraphrynus laevifrons J Exp Biol. 2016;jeb:149823.

6. Wiegmann DD, Hebets EA, Gronenberg W, Graving JM, Bingman VP. Amblypygids: model organisms for the study of arthropod navigation mechanisms in complex environments? Front Behav Neurosci. 2016;10:47.

7. Igelmund $\mathrm{P}$, Wendler $\mathrm{G}$. The giant fiber system in the forelegs (whips) of the whip spider Heterophrynus elaphus Pocock (Arachnida: Amblypygi). J Comp Physiol A. 1991;168:63-73.

8. Igelmund P, Wendler G. Morphology and physiology of peripheral giant interneurons in the forelegs (whips) of the whip spider Heterophrynus elaphus Pocock (Arachnida: Amblypygi). J Comp Physiol A. 1991;168:75-83.

9. Foelix R, Hebets E. Sensory biology of whip spiders (Arachnida, Amblypygi). Eileen Hebets Publications. 2001;32.

10. Hebets EA, Chapman RF. Electrophysiological studies of olfaction in the whip spider Phrynus parvulus (Arachnida, Amblypygi). J Insect Physiol. 2000;46:1441-8.

11. Igelmund P. Morphology, sense organs, and regeneration of the forelegs (whips) of the whip spider Heterophrynus elaphus (Arachnida, Amblypygi). J Morphol. 1987;193:75-89.

12. Barth FG, Stagl J. The slit sense organs of arachnids. Zoomorphologie. 1976;86:1-23.

13. Scheuring L. Die Augen der Arachnoideen. I. Zool Jahrb Abt Anat Ontog Tiere. 1913;33:553-636

14. Weygoldt P. Untersuchungen zur Embryologie und Morphologie der Geißelspinne Tarantula marginemaculata CL Koch (Arachnida, Amblypygi, Tarantulidae). Zoomorphologie. 1975:82:137-99.

15. Paulus HF. Eye structure and the monophyly of the Arthropoda. In: Gupta AP, editor. Arthropod phylogeny. New York: Van Nostrand Reinhold Company; 1979. p. 299-83.

16. Hanström B. Vergleichende Anatomie des Nervensystems der wirbellosen Tiere: unter Berücksichtigung seiner Funktion. Berlin: J. Springer; 1928.

17. Giribet G. Current views on chelicerate phylogeny - a tribute to Peter Weygoldt. Zool Anz. 2018;273:7-13.

18. Weygoldt P, Paulus HF. Untersuchungen zur Morphologie, Taxonomie und Phylogenie der Chelicerata. II. Cladogramme und die Entfaltung der Chelicerata. Zeitschrift für zoologische Systematik und Evolutionsforschung 1979:17:177-200

19. Wheeler WC, Hayashi CY. The phylogeny of the extant chelicerate orders. Cladistics. 1998:14:173-92.

20. Shultz JW. A phylogenetic analysis of the arachnid orders based on morphological characters. Zool J Linnean Soc. 2007;150:221-65.

21. Legg DA, Sutton MD, Edgecombe GD. Arthropod fossil data increase congruence of morphological and molecular phylogenies. Nat Commun. 2013;4:1-7.

22. Garwood RJ, Dunlop J. Three-dimensional reconstruction and the phylogeny of extinct chelicerate orders. PeerJ. 2014;2:e641.

23. Klußmann-Fricke BJ, Wirkner C. Comparative morphology of the hemolymph vascular system in Uropygi and Amblypygi (Arachnida): complex correspondences support Arachnopulmonata. J Morphol. 2016: 277:1084-103.
24. Regier JC, Shultz JW, Zwick A, Hussey A, Ball B, Wetzer R, Martin JW, Cunningham CW. Arthropod relationships revealed by phylogenomic analysis of nuclear protein-coding sequences. Nature. 2010;463:1079-83.

25. Sharma PP, Kaluziak ST, Pérez-Porro AR, González VL, Hormiga G, Wheeler WC, Giribet G. Phylogenomic interrogation of Arachnida reveals systemic conflicts in phylogenetic signal. Mol Biol Evol. 2014;31:2963-84.

26. Shultz JW. Evolutionary morphology and phylogeny of Arachnida. Cladistics. 1990;6:1-38.

27. Homberg U. Evolution of the central complex in the arthropod brain with respect to the visual system. Arthropod Struct Dev. 2008;37:347-62.

28. Strausfeld NJ, Barth FG. Two visual systems in one brain: neuropils serving the secondary eyes of the spider Cupiennius salei. J Comp Neurol. 1993;328:43-62.

29. Strausfeld NJ, Weltzien P, Barth FG. Two visual systems in one brain: neuropils serving the principal eyes of the spider Cupiennius salei. J Comp Neurol. 1993:328:63-75.

30. Lehmann T, Heß M, Melzer RR. Wiring a periscope - ocelli, retinula axons, visual neuropils and the ancestrality of sea spiders. PLoS One. 2012;7.

31. Lehmann $T$, Heß M, Wanner G, Melzer RR. Dissecting a neuron network: FIB-SEM-based 3D-reconstruction of the visual neuropils in the sea spider Achelia langi (Dohrn, 1881)(Pycnogonida). BMC Biol. 2014;12:59.

32. Lehmann T, Lodde-Bensch E, Melzer RR, Metz M. The visual system of harvestmen (Opiliones, Arachnida, Chelicerata) - a re-examination. Front Zool. 2016;13:50.

33. Lehmann T, Melzer RR. Looking like Limulus? - Retinula axons and visual neuropils of the median and lateral eyes of scorpions. Front Zool. 2013;10:40.

34. Lehmann T, Melzer RR, Hörnig MK, Michalik P, Sombke A, Harzsch S. Arachnida (excluding Scorpiones). In: Schmidt-Rhaesa A, Harzsch S, Purschke $\mathrm{G}$, editors. Structure and evolution of invertebrate nervous systems. Oxford: Oxford University Press; 2016. p. 453-77.

35. Lehmann T, Melzer RR. A tiny visual system-retinula axons and visual neuropils of Neobisium carcinoides (Hermann, 1804) (Chelicerata, Arachnida, Pseudoscorpiones). Zool Anz. 2017:273(In honor of Peter Weygoldt):164-72.

36. Battelle B-A. The eyes of Limulus polyphemus (Xiphosura, Chelicerata) and their afferent and efferent projections. Arthropod Struct Dev. 2006;35:261-74.

37. Battelle B-A, Sombke A, Harzsch S. In: Schmidt-Rhaesa A, Harzsch S, Purschke G, editors. Xiphosura. In Structure and Evolution of Invertebrate Nervous Systems. Oxford: Oxford University Press; 2016. p. 428-42.

38. Calman BG, Lauerman MA, Andrews AW, Schmidt M, Battelle B-A. Central projections of Limulus photoreceptor cells revealed by a photoreceptorspecific monoclonal antibody. J Comp Neurol. 1991;313:553-62.

39. Chamberlain SC, Barlow RB. Neuroanatomy of the visual afferents in the horseshoe crab (Limulus polyphemus). J Comp Neurol. 1980;192:387-400.

40. Fleissner $\mathrm{G}$. Intracellular recordings of light responses from spiking and nonspiking cells in the median and lateral eyes of the scorpion. Naturwissenschaften. 1985;72:46-8.

41. Paul DH. A neurophylogenist's view of decapod Crustacea. Bull Mar Sci. 1989:45:487-504.

42. Harzsch S. Neurophylogeny: architecture of the nervous system and a fresh view on arthropod phylogeny. Integr Comp Biol. 2006;46:162-94.

43. Harzsch S. The architecture of the nervous system provides important characters for phylogenetic reconstructions: examples from the Arthropoda. Species, Phylogeny and Evolution. 2007;1:33-57.

44. Strausfeld NJ. Arthropod brains: evolution, functional elegance, and historical significance. Cambridge: Harvard University Press; 2012.

45. Strausfeld NJ. Andrew DR. A new view of insect-crustacean relationships I. inferences from neural cladistics and comparative neuroanatomy. Arthropod Struct Dev. 2011:40:276-88.

46. Harzsch S, Vilpoux K, Blackburn DC, Platchetzki D, Brown NL, Melzer RR, Kempler KE, Battelle B-A. Evolution of arthropod visual systems: development of the eyes and central visual pathways in the horseshoe crab Limulus polyphemus Linnaeus, 1758 (Chelicerata, Xiphosura). Dev Dyn. 2006; 235:2641-55.

47. Meyer-Rochow V. Aspects of the functional anatomy of the eyes of the whipscorpion Thelyphonus caudatus (Chelicerata: Arachnida) and a discussion of their putative performance as photoreceptors. J R Soc NZ. 1987;17:325-41.

48. Steinhoff PO, Sombke A, Liedtke J, Schneider JM, Harzsch S, Uhl G. The synganglion of the jumping spider Marpissa muscosa (Arachnida: Salticidae): insights from histology, immunohistochemistry and microCT analysis. Arthropod Struct Dev. 2017;46:156-70.

49. Long SM: Spider Brain Morphology \& Behavior. Doctoral Dissertation. University of Massachusetts Amherst, 2016. 
50. Kovoor J, Muñoz-Cuevas A, Ortega-Escobar J. The visual system of Lycosa tarentula (Araneae, Lycosidae): microscopic anatomy of the protocerebral optic centres. Italian Journal of Zoology. 2005;72:205-16.

51. GCA SR. Contribution à l'étude du cerveau chez les arthropodes trachéates. Faculte des sciences de Paris: Academie de Paris; 1890.

52. Breidbach $\mathrm{O}$, Wegerhoff R. Neuroanatomy of the central nervous system of the harvestman, Rilaena triangularis (HERBST 1799) (Arachnida; Opiliones): principal organization, Gaba-like and serotonin-immunohistochemistry. Zool Anz. 1993;230:55-81.

53. Boissin L, Cazal M. Étude du système nerveux et des glandes endocrines céphaliques de l'adulte femelle d'Hysterochelifer meridianus (L. Koch) (Arachnide, Pseudoscorpion, Cheliferidae). Bull Soc Zool Fr. 1969;94:263-8.

54. Winter G. Beiträge zur Morphologie und Embryologie des vorderen Körperabschnitts (Cephalosoma) der Pantopoda Gerstaecker, 1863: Entstehung und Struktur des Zentralnervensystems. Zeitschrift für zoologische Systematik und Evolutionsforschung. 1980;18:27-61.

55. Melzer RR, Petyko Z, Smola U. Photoreceptor axons and optic neuropils in Lithobius forficatus (Linnaeus, 1758) (Chilopoda, Lithobiidae). Zool Anz. 1996; 235:177-82.

56. Sombke A, Harzsch S. Immunolocalization of histamine in the optic neuropils of Scutigera coleoptrata (Myriapoda: Chilopoda) reveals the basal organization of visual systems in Mandibulata. Neurosci Lett. 2015:594:111-6

57. Fanenbruck M, Harzsch S. A brain atlas of Godzilliognomus frondosus Yager, 1989 (Remipedia, Godzilliidae) and comparison with the brain of Speleonectes tulumensis Yager, 1987 (Remipedia, Speleonectidae): implications for arthropod relationships. Arthropod Struct Dev. 2005;34:343-78.

58. Fanenbruck M, Harzsch S, Wägele JW. The brain of the Remipedia (Crustacea) and an alternative hypothesis on their phylogenetic relationships. Proceedings of the National Academy of Sciences. 2004; 101:3868-73

59. Strausfeld NJ. The evolution of crustacean and insect optic lobes and the origins of chiasmata. Arthropod Struct Dev. 2005;34:235-56.

60. Tanaka G, Hou X, Ma X, Edgecombe GD, Strausfeld NJ. Chelicerate neural ground pattern in a Cambrian great appendage arthropod. Nature. 2013;502:364.

61. Uehara A, Uehara K, Ogawa K. Fine structure of the anteromedial eye of the liphistiid spider, Heptathela kimurai. The Anatomical Record. 1994;240:141-7.

62. Uehara A, Toh Y, Tateda H. Fine structure of the eyes of orb-weavers, Argiope amoena L. Koch (Araneae: Argiopidae). Cell Tissue Res. 1977;182:81-91.

63. Uehara A, Toh Y, Tateda H. Fine structure of the eyes of orb-weavers, Argiope amoena L. Koch (Aranea: Argiopidae). Cell Tissue Res. 1978;186:435-52.

64. Melamed J, Trujillo-Cenóz O. The fine structure of the visual system of Lycosa (Araneae: Lycosidae). Cell Tissue Res. 1966;74:12-31.

65. Eakin RM, Brandenburger JL. Fine structure of the eyes of jumping spiders. J Ultrastruct Res. 1971;37:618-63.

66. Blest AD. The fine structure of spider photoreceptors in relation to function. In: Neurobiology of arachnids: Springer; 1985. p. 79-102.

67. Altman JS, Tyrer NM. Filling selected neurons with cobalt through cut nerves In: Strausfeld NJ, Miller TA, editors. Neuroanatomical techniques: insect nervous system. New York: Springer; 1980. p. 373-402.

68. Wigglesworth VB. The use of osmium in the fixation and staining of tissues. Proc R Soc Lond Ser B. 1957;147:185-99.

69. Leise EM, Mulloney B. The osmium-ethyl Gallate procedure is superior to silver impregnations for mapping neuronal pathways. Brain Res. 1986;367:265-72.

70. Mizunami M, Iwasaki M, Nishikawa M, Okada R. Modular structures in the mushroom body of the cockroach. Neurosci Lett. 1997;229:153-6.

71. Sombke A, Lipke E, Michalik P, Uhl G, Harzsch S. Potential and limitations of $X$-ray micro-computed tomography in arthropod neuroanatomy: a methodological and comparative survey. J Comp Neurol. 2015;523:1281-95.

Ready to submit your research? Choose BMC and benefit from:

- fast, convenient online submission

- thorough peer review by experienced researchers in your field

- rapid publication on acceptance

- support for research data, including large and complex data types

- gold Open Access which fosters wider collaboration and increased citations

- maximum visibility for your research: over $100 \mathrm{M}$ website views per year

At $\mathrm{BMC}$, research is always in progress.

Learn more biomedcentral.com/submissions 